\title{
THE SILENT SELF: VALENTINE ACKLAND'S DIARIES AFTER 1949
}

\author{
Ailsa Granne
}

But it is only I,

Stricken myself, who cry

The spring is come, is dumb, and no birds sing.

Valentine Ackland

Sylvia Townsend Warner and Valentine Ackland spent a lifetime writing to, for and about each other. In view of this, it is interesting to ask why Ackland, despite writing journals, poems, and short stories, nevertheless chose to represent herself as silent.

In the immediate aftermath of the Elizabeth Wade White affair in 1949 Warner feared that she had lost her ability to write as evidenced by diary entries such as the following written on March 17th 1950:

I have not schemed. I have had no ambition. I have created nothing, for the poems that have broken out of me were no more 
creative than the sweat of anguish. I have done some pot boilers.

(Warner, 1995, p.162)

As time passed however, Warner recovered her literary skills and her work took on a new momentum: The Flint Anchor was published in 1954, and she was commissioned to translate Proust's Contre Saint-Beuve in the same year, while in 1955 she published Winter in the Air. One consequence of this was that Warner's and Ackland's lives began to diverge. As Claire Harman comments in her biography of Warner, 'Sylvia's persistent success meant that it was no longer possible, in this matter of writing, for them to treat each other as equals, an admission which cost them both dear.' (1991, p.220). However, in her diary of the last day of 1951 , Warner wrote this:

A year of threats \& dangers, \& sad [un] certainties of my Love's health - \& yet a year full of solace \& happiness, as we reknit together, and 1949 withdraws \& the wound heals. (Warner, 1995, p.184)

Ackland's diaries, however, tell a very different story, for she wrote on February $6^{\text {th }} 1951$ :

I found myself extremely near to despair, as I thought I was never to be a poet now - and after so long all I had ever reached was a very poor mediocrity: and I knew myself to have no more power in me. ... I shall not again (ever again by God's grace) try to emerge as a "poet" nor ever again call myself a "Writer". (Unpublished diaries.)

And on August 1 $7^{\text {th }} 1951$, 
When I was thoroughly sodden I wrote with a kind of stumbling blind felicity - didn't I? And now I am merely good - and DUMB

(Unpublished diaries.)

The following month she wrote:

At her request I took my Love out last evening, between 6 and 8 for a Drive; she had finished a piece of writing and was very tired. I am myself so very tired because I have not finished any piece of writing ever so we made a queer pair; but that was not spoken of....

(Unpublished diaries September $8^{\text {th }} 1951$ )

And two days later:

I am ashamed - much more than that - I am cast down into a pit of self-despising, when I realise (at times like today when she reads to me out of her diary, in an effort to trace this or this) to realise how overwhelmingly I have laid my weight on her over the years - . . . in fact have whined. It wd. be so much better to have raged - but although I often want to, I dare not, because whenever I let myself roar in fury at being so impeded by backache, mastitis and god- knows-whatnot, then I feel such a desperate frantic, lunatic desire to go on and on ROARING in rage, that $I$ am really afraid that $I$ wd. go mad if I let myself start. No: the thing to do is to keep quiet about it: and learn how NOW.

(Unpublished diaries Sept. $10^{\text {th }} 1951$ )

What is interesting in these extracts is to note who speaks, who is silent, who writes, and whether or not their diaries form part of the conversation between the two women'. 
Ackland clearly feels she has lost her ability to write good poetry and has as a consequence become dumb. Rendered speechless she also becomes nameless, never again can she be called 'poet' or 'writer'. It is as though her identity has been challenged, her notion of selfhood undermined. Warner in contrast, even though this is Ackland's diary, can both speak and write. She has 'finished a piece of writing' and reads aloud from her own diaries. When Ackland allows herself a voice, she describes it as a whine or roar. It is also clear that in their shared life one topic was taboo: Ackland's inability to write and be published ('but that was not spoken of'). The nature of the silence that, paradoxically, Ackland is so eloquent about requires further thought, for at the same time that she was frequently writing in her diary about her lack of creativity, she was also producing short stories and poetry, of which the following, written in January 1952, is an example:

It would be most foolish, surely,

After such long struggles, so much hard fighting,

This anonymous afternoon to surrender at Discretion -

It would be foolish surely?

Especially as I am alone now,

Never in forty years have been deeper sunk

In loneliness: so that to summon her,

Or her, or any of them, would be

Intolerable effort, surely, intolerable indiscretion;

Since they are all dismissed, and suitably

Rewarded - or if not suitably,

At least rewarded by someone other than me.

(Ackland, 2008, p.171)

The most striking feature of the poem is that the voice within it seems to be constantly calling the present into question, speculating on alternatives to the status quo. 'Never in forty years have been deeper sunk in loneliness' 
stands in marked contrast to Warner's diary entry of New Year's Eve 1951, 'we re-knit together, and 1949 withdraws \& the wound heals', given that the two texts were written less than a month apart. Within the text of the poem the poet/ Ackland voice appears to be debating whether or not it may be worthwhile to embark on another 'intolerable indiscretion', whether or not to summon 'her/, Or her, or any of them', which, given she had only just emerged from the turmoil of the Wade White affair, is somewhat surprising. The repetition of the word 'surely' signals that Ackland is asking questions of herself, however in the second and final stanza the voice concludes with this instruction: 'And be still; be very solitary and still'. While 'It would be most foolish' tells another story to that told in Warner's diary the fact that both stories have been 'told', in their respective diaries, and in Ackland's poem, further complicates Ackland's assertion that she is dumb and silent.

Given the amount of Ackland's written material there is in the Dorchester archive, including her extensive diaries, the question has to be asked: in what sense was she silent? Philippe Lejeune in his book On Diary (2009) asserts that before becoming a text, keeping a private diary is a practice. I believe that intuitively Ackland was aware of this. Her diaries did not, for her, count as texts, and were discounted as evidence of her status as a writer. However, people keep diaries for many reasons. They can form a historical record, act as a safety valve in times of difficulty, and be a site for self-formation. I believe the latter is true for Ackland. In particular her diaries represented a place where she could construct a voice without recourse to Warner. It is clear she didn't much like the self that she formed, but self-disgust is a constant presence in almost all of her texts. What is more interesting, and indeed paradoxical, is that the self she constructed is represented as silent.

The importance of Ackland's diary writing practice is, I believe, this: it helped her to resist, in part at least, the silent self, and this resistance bore fruit in other genres, particularly in her poetry. In other words I am suggesting 
that the practice of diary keeping is so powerful that it can facilitate the emergence of a voice, even when the writer designates herself as silent. The evidence for this is that throughout her life Ackland did continue to write poetry. Wendy Mulford in her book This Narrow Place devotes considerable time to evaluating Ackland's poems, and concludes her final chapter with the comment; "Not the least surprising thing about this surprising woman was that by the end of her life she was a poet reaching the height of her powers, all unknown' (Mulford, 1988, p.228). Crucial to our understanding of the nature of Ackland's construct of herself as silent are the words 'all unknown'2.

In exploring further the paradox of Ackland's representation of herself as silent and dumb, whilst continuing to write, I wish to consider a poem she wrote in May 1955:

This is the silent spring:

Green and beautiful, gold and beautiful; everything

Suddenly born anew and blossoming

As if death were past and all the flowers grew

Safely in Paradise at last.

And yet it seems to me that no birds sing -

But in the coloured garden, over the meadow's shining,

Through the clear light of the air, silent on wing

The sweet birds fly-

But it is only I,

Stricken myself, who cry

The spring is come, is dumb, and no birds sing.

(Ackland, 2008, p.177)

The evidence that she has emerged from a deathlike winter surrounds the poet. 'All is green and beautiful, gold and beautiful'. However, it soon appears that in this 
particular paradise something is amiss: what is expected, but is lacking, is birdsong. As well as her anxiety about her status as a poet, another theme that runs through Ackland's writing in both her diary and in her poems, is not only that her own creativity and talent have been lost, but that others remain creative. Although the voice within the poem declares 'This is the silent spring', the poet becomes aware that this is not true for everyone: 'But it is only I, / Stricken myself who cry/ The Spring is come, is dumb, and no birds sing'.

There is some evidence that Ackland, living as she did with the prolific Warner, suffered from a degree of professional jealousy, as the following diary entry makes clear:

My Love is writing again: I am thankful for two reasons: because I love her and would not have her suffer this dreadful anguish,... and because I profoundly admire her genius and have many times in a week my own private fears and terrors in case it is being starved or maimed by the life she lives here with me.....but also I suffer from the most appalling and disgraceful pangs of envy...so that [I] can scarcely endure to see her abstracted face, to hear her happy typewriter, to watch the evening pass into night and the night into midnight and know that she is able to work (Unpublished diaries, Oct. 18 ${ }^{\text {th }}$ 1951)

Furthermore, earlier in the year Ackland had sent some short stories to Cornhill magazine, but in the event they were all returned with a rejection slip:

I said - very weakly as I thought when I said it but I could not forbear - that I was in a state about it and very much in need of counsel: but she had at that time a wireless programme she wanted to hear and no more 
has been said about it at all. I try not to mention any "work" of mine at all, for it now quite unmistakably evokes this sort of "freezing".

(Unpublished diaries, Nov. 29 1951 )

It is evident from these two examples that Ackland's proximity to the hard working and productive Warner added to her anguish. The contrast between her own dumbness, as she perceived it, and the creativity of others, is most apparent in an episode which occurred in May 1952 when Warner received a recording of Paul Nordoff's setting of some of her poems written in 1949. The cycle is entitled 'Lost Summer'. Warner wrote about listening to Nordoff"s music in a diary entry of May $12^{\text {th }} 1952$ :

I took heart enough to unpack Paul's parcel: Lost Summer was in. ... The music I still cannot assess, for my heart is too much in it. But listening to the 2 river songs I could say, It is justified, I can accept that then, for this music that has come out of it. And then I fell into an agony of grief to think that for my Love, \& that wretched Elizabeth, there is no such foison - that all was planted in a dead \& killing soil.

(Warner, 1995, p.188)

Four days later on $16^{\text {th }}$ May she wrote, 'I called her in to listen to 'Lost Summer'. Alas that it had to grieve her so; but after this first hearing, the music will reconcile her, perhaps'. (Warner, unpublished diaries). Ackland's response to listening to the music is recorded in her diary for that day:

although I could not hear more than a word or a half phrase from her poems here and there, yet my heart heard the whole elegy and wept and wept until at last my eyes, uselessly and trivially, spilled tears too. But 
for what? For the woe, I thought, and the loss and the falling apple blossom and the turning year and the dying heart and the sun becoming wintry and small and going further and further away[.] But it was not only - if only can be said - it was not only for that: it was from a kind of rapt envy ... but yet it was a yearning and still an unimpassioned yearning of longing that from all that loss and ruin and anguish and despair I too might have brought some fruit or flower, even - to show in my hand after everything else has fallen away. But it has been sterile for me ... and I thought "Let me hide - let me go - "and knew the urgency that Judas felt as he hurried out to the field, and how thankfully he handled the rope to put it about his throat. It is hard to tell more and I do not expect I shall ever now. I sat there like a stone, and when I wept I felt as if I were merely a stone sweating its few drops of moisture-which had not come, could never come, from its own stony heart, but were superficial, comfortless and could not cool or wash it or be taken as any token of living water or living life within the heart of the stone.

(Unpublished diaries)

In this remarkable diary entry Ackland expresses the hope that as a consequence of the events of 1949 she too might have brought forth 'some fruit or flower'. However the reality is that she has been turned to stone, incapable of producing 'living water or life'. This is clearly an account of her inability, as she sees it, to write. Warner's remark in her diary that 'after this first hearing the music will reconcile her, perhaps', seems very wide of the mark, even callous, and suggests that on the subject of their shared writing life there was little or no conversation. 
One of the characteristics of diaries, particularly those of writers, is that on occasions they lose their moorings in the everyday and begin to resemble other genres. I do not, however, believe this to be the case in Ackland's discursive diary entry of May $16^{\text {th }}$. Rather I think that this diary record is a spontaneous response to her experience of that day. Its textual allies are the deeply troubled diary entries of 1949 written by Warner, rather than, for example, a genre such as fiction. One of the reasons I suggest that this diary entry was originally distinct from fiction is that at a later date Ackland, recognising the power of her writing of May $16^{\text {th }}$, made a definite attempt to turn it into a short story called 'Time Spent'. In doing this she is behaving as Warner often did, using her actual life experiences as material for fictional writing. Where Ackland does differ from Warner is that she makes little attempt to spin 'a true observation into another whimsical paragraph', but quotes verbatim, and almost in its entirety, the diary entry, so that after setting the scene, the story proceeds with 'How uselessly and trivially now my own tears fall', and continues with the words she recorded in her diary. She does make some changes, the most important of which are that the Warner/poet figure changes gender and is designated male, and she also elaborates on the 'rapt envy', with which she listened to the music.

These were the words he [the poet/ Warner] had never spoken. While the tempest raged, he had kept them safe and dry, kept them as seeds for a new sowing. He had watched them patiently, afterwards, as they grew and flowered at last into poems; and at last they dropped their bright petals into this tide becoming the songs she had heard as she begins to drown.

"If only I too, from that ruin and loss, that anguish, that despair, might have put out some flower, one flower, after everything else had fallen away. But it has been sterile 
for me. And now I sit in this chair, hearing the music and the words and knowing that he, in his truth, remained potent, able again to engender out of himself and fructify this sad little musician too. . . . For sad he was, and little" she thought bitterly, "Until our disaster became his fortune!"

(Unpublished short story)

In this extract from 'Time Spent' Ackland seems to both suggest and resent the fact that Warner had been able to make poetic capital out of their personal tragedy, while she herself had remained 'sterile'. The word 'sterile' is taken directly from the diary entry, however, in the short story it ushers in a diatribe against both Warner and Nordoff. The story concludes:

"Without my fall, the disaster could not have been completed. Because my seed rotted, his has flourished. A dirty field, drowned in a salt flood - but there, outside the window, bright gold, and silver grasses; and with me in the room here, the two who have not died."

I have described how Ackland used her diary record of the events of May $16^{\text {th }}$ almost in its entirety in 'Time Spent'. I therefore think that making an autobiographical reading of the story is both justified and inevitable. 'Because my seed rotted, his has flourished' is therefore a fairly shocking statement, suggesting as it does that there has been some ghastly exchange of creativity between the poet (Warner) and the listener (Ackland). Finding no role for herself as a creative artist in the trio, Ackland assumes the place of martyr, seeing her own death as the origin of the creativity of others. Of note too, is the way in which her language in 'a dirty field drowned in a salt flood' resonates with Warner's comment in her diary of May $16^{\text {th }}$, that for Ackland (and Wade White) 'all was planted in a dead \& killing soil'. 
Whilst I consider that one explanation of Ackland's construct of herself as silent arises from the professional jealousy she felt at observing Warner's success, other dynamics have now emerged which need further thought. In 'Time Spent' a link is established between the creativity of the poet and the silence of the listener, which implies that in some way Warner may be implicated in Ackland's silence.

An interesting conversation occurred between the two women on $25^{\text {th }}$ of September 1951 and is recorded by both of them in their diaries. They had visited Weymouth that day, and Warner records their conversation on the return journey as follows:

I began to talk of seasons, and how one's strongest feelings spring from the first landscape - my suburban autumns, \& my feeling for Middlesex cottages square \& yellow-brick, against the winter sunset and hers, she said, a muddy lane between brambles \& thistles \& beyond a great vacancy of sky - the Winterton shooting. The Traherne child that lives on into the grown up artist who still keeps that brilliant eye. Not me, now, she said - with such weight of sorrow. The impulse to express these things has gone dead in me. But you still see them? No. I began to, at Great Eye, but after that influenza I lost it again through feeling so oppressed with sick-ness. I could not dispute it, for plainly she said it in truth. But I wish she had not said it, saying can become such a slab-stone.

(Warner, 1995, p.180)

Ackland's diary records the following:

$26^{\text {th }}$ Sept. I forgot to say yesterday, that during our drive back along the road to Warmwell I made a passing reference - 
without first meaning to - to my present state of dreadful stupor: it was curious (it was then horrible but it is now curious) to find myself become absolutely idiotic directly I had said even so much...I went on - still more violently against my will - to say the truth was: I had had a slight talent, and it had run out ... But I did not manage to explain anything. I was in truth an idiot. I mumbled. I stuck. I became silent. My Love then asked if I had become maimed or crippled by this second mishap of Elizabeth - and I said No. But I do not know. I think I said that for two reasons: that otherwise I should be misunderstood as blaming her for what was either no fault - or more mine than hers (I am sure of that) and also that I was ashamed to admit at all to my Love, or too much to myself, that I DO think so. But here I now say it: I DO think so. For in 1948 I was in the midst of that New Spring, and what poems I was writing may have been inadequate, but they were - to me inside myself - new and spring might have become summer: or even if it had stayed spring, it would have blossomed with a promise of fruit somewhere else, maybe. And I was writing prose too. And I was feeling my wits begin to knit together again after that dreadful scattering... whatever else of me may have survived and be still more or less intact, my power to see, to hold, to make has been completely wrecked and dislocated. ...

This is not to make me a liar when I told my Love two days ago that I was happy. I am in a state or a condition of happiness in loving her.

(Ackland, unpublished diaries) 
Reading this diary entry makes it even clearer why 'This is the silent spring' is such a sad and arresting poem. Written in spring 1955, the poem is a reflection on the fact that for Ackland (it was very different for Warner), there was no creative recovery from the events of 1949 , only wreckage and dislocation.

The most noticeable feature of the parallel accounts quoted above is how Ackland seems unable to articulate her anguish - 'I mumbled. I stuck. I became silent' while Warner thinks that Ackland has said too much: 'But I wish she had not said it, saying can become such a slabstone'. Rather than a conversation between women these exchanges as recorded in their diaries seem more like a negotiation around silence. In order to explore this further it is necessary to review the history of their relationship as poets, as artists who did or did not keep 'that brilliant eye'.

When the relationship between the two poets began in the 1930, Warner, as a published poet and successful writer, acted at times as a mentor for Ackland. In a letter to Warner of $5^{\text {th }}$ November 1930, she writes, 'Please, will you bring those poems down when you come? I would be very much helped if you would pull out the dead ones for me. I need to learn if you will teach me' (Warner, 1998, p.29). Warner also attempted to get Charles Prentice, who had published her own work, to publish Ackland's poetry. In this however she was unsuccessful. Warner, who was not easily deflected from something she had determined to do, then collaborated with Ackland in Whether a Dove or Seagull, which was published by Viking in USA in 1933, then in Britain by Chatto and Windus in 1934. Later on in the relationship Warner was to wonder whether this strategy to get Ackland published had achieved the desired result:

Since then I have come to doubt whether Valentine gained or suffered by a joint book. It showed her poems on the printed page an experience by which one learns and may be stimulated; but on the other hand it carried a sort of cadetship implication 
(fatally reinforced by an entry in the Chatto and Windus List of 1934: Ackland, Valentine - see Warner, S.T.)

(Warner, 1998, p.114)

Ackland's perspective on the publication of Whether a Dove or Seagull has recently become available to us through a rather odd set of circumstances. Both women were members of the Communist party in the 1930s, and as a consequence their letters were intercepted, read, and copied by the security service. When MI5 recently opened up some of their records to the public the Warner/Ackland archive in Dorset County Museum acquired copies of their intercepted letters. In one such, a letter of $20^{\text {th }}$ March 1935 to Tom Wintringham (a Communist party official and editor of New Left Review) Ackland, in the process of asking his advice about her poetry, writes the following about Whether a Dove or Seagull:

Damming to come out with Sylvia, you see, and to be judged either as an imitator (which I am not, consciously,) or else as a protégée. But we had to do it, and it was a noble thing to do, but very stupid.

(Unpublished letter)

Clearly Ackland believed the close proximity of her poems in the text to the better poems of Warner was detrimental both to her talent and to her reputation. However, the good poems are not all Warner's, and in the original American edition, the poems were published without attribution. More important I think is Ackland's sense that she may be thought of as a protégée of Warner, insufficient as a poet to stand on her own. A diary entry of $31^{\text {st }}$ August 1952 supports this perspective. Here she writes how she had

seen some time ago a letter on my Love's table asking whether she knew anything about her collaborator Valentine Ackland 
and could give any information to enquirer... I do not know how she answered this, but it made me feel myself one of a crowd of strange, shifting figures, who sometimes, at odd moments in the time of the world, become solid for a while, and the subject of speculation.

(Unpublished diaries)

It is clear from Ackland's diary entry that in this remark she is thinking of individuals like De Quincy's brother or the person from Porlock who appear for a moment in the texts of famous writers, never to be heard of again. 'Becoming solid for a while' suggests that Ackland considers that the only life she has comes from her proximity to Warner in much the same way as her poetry only appears in print and has a textual life when ushered into print by their adjacency to the words of the more famous poet. This raises the possibility that she is aware that in some way her existence is predicated on Warner; that until Warner calls her into existence as a poet (by publishing her) she remains dumb.

Whilst I continue to think that Ackland's talents as a writer were limited, and that this was the primary reason she remained mostly unsuccessful and unheard, I now also believe that some of her silence had its origin in her close proximity to Wamer. It is clear in the many examples I have cited from Ackland's diary that Warner did not, in later years, choose to advise Ackland about her poetry, nor help her when she ran into difficulties getting her work published. What is particularly striking is that she did not wish to ever speak about this. Earlier in this article, for example, I referred to the topic as one which was 'taboo'. This may be an indication that Warner was aware of the effect that her own success had on Ackland, that she knew she was the better poet and writer, but there may be another explanation which should also be considered.

From the early 1930s the psychoanalyst Melanie Klein used the term 'parts of self' to make a very specific claim about the mechanisms underpinning division, namely that they are always projective. We divide ourselves in order 
to 'lose' parts of ourselves. We project unwanted parts of ourselves on to others. Klein's theory seems pertinent to Warner and Ackland, as we know that particularly around 1949 Warner was extremely anxious about her ability to write and it could be that this resulted in her unconsciously projecting onto Ackland that part of herself that was a dumb poet and voiceless writer. In so doing she perhaps silenced Ackland as a means of purging her own fears of silence. Having done that she necessarily had to turn away from this version of self, and distance herself from its manifestation in Ackland. This albeit unconscious transaction between the two writers is not so much a conversation, but a repudiation of silence by one and a concomitant acquisition of dumbness by the other. One consequence of this reading of the Ackland/ Warner dialogue is that Ackland's statement in 'Time Spent', 'Because my seed rotted, his has flourished', takes on a new resonance, as do her diary entries such as that of January $20^{\text {th }}$ 1954: 'I do not think anything else has happened, except that I have lost - lost - lost. My Love has written another book'. (Ackland, unpublished diaries).

Towards the end of her life and after her death Warner did publish many of her poems ${ }^{4}$. This occurred after 1956 and the difficulties that arose as a consequence of Ackland's return to the Roman Catholic Church. I think that at this time Warner became very aware (in part as a result of reading Ackland's diaries) of the depth of her friend's sorrow for her 'lost' poems. However in the light of my earlier arguments, this publishing history raises even more questions.

Reading Warner and Ackland's diaries in parallel (both published and unpublished) provides some new perspectives on their relationship as two writers, and adds to our understanding of their many accounts of their long love and friendship. Both Ackland's desire to be remembered and her love for Warner are reflected in the following poem written in the 1960s, in which she commends to those who 'sift our dust' the life they shared: 
I have tried very hard to write

Some poem about love which might

Explain to those who sift our dust

When we have gone what rite they must

Perform, what ceremonial dance

Follow in its intricacy

If they will make their love as we

Made ours: out of a moment's chance

A timeless immortality ${ }^{5}$.

\section{NOTES}

1. In designating the textual dialogue between Warner and Ackland as a 'conversation between women' I am making reference to the title of the portrait painted of Minna and Sophia in Summer Will Show (2009) and Claire Harman's reference to it in her 'Introduction' to this edition(p. $x$ ).

2. Ackland's desire to be known, recognised and remembered is another theme that runs through her writing as evidenced, for example, in her choice of Horace's cry of poetic continuity as her epitaph. Non Omnis Moriar - I shall not altogether die.

3. This is a quotation from Warner's short story 'Happiness' in A Stranger with a Bag (Warner, 1966, p.91) in which Warner provides us with some interesting insights as to how a writer may collect her material, and the relationship between the diaries of a diary keeping author and her fiction.

4. Twenty- Eight Poems by Valentine Ackland, (1957); Later Poems by Valentine Ackland, (1970); The Nature of the Moment, (1973); Further Poems by Valentine Ackland, (1978)

5. Mulford quotes this poem by Ackland in This Narrow Place (p.228). The text was still being worked on by the writer at the time of her death and is in the Manisty papers in the Dorchester Archive 


\section{WORKS CITED}

ACKLAND, V. (2008) Journey from Winter: Selected Poems. Ed. Frances Bingham. Manchester: Carcanet.

HARMAN, C. (1991) Sylvia Townsend Warner. A Biography. London: Minerva.

MULFORD, W. (1988) This Narrow Place. Sylvia Townsend Warner and Valentine Ackland: Life, Letters and Politics, 1930-1951. London: Pandora.

WARNER, S.T. (1966) A Stranger with a Bag. London, Chatto \& Windus.

(1995) The Diaries of Sylvia Townsend Warner. Ed. C. Harman. London: Virago (1998) I'll Stand by You. Selected Letters of Sylvia Townsend Warner and Valentine Ackland with Narrative by Sylvia Townsend Warner. Ed. S. Pinney. London, Pimlico. 


\section{ERRATUM}

The Journal of the Sylvia Townsend Warner Society 2011 carried an article by Richard Searle, 'Sylvia Townsend Warner and Tudor Church Music', to which I appended the wrong illustration. The correct illustration has been reproduced below, with apologies to Richard Searle and the Oxford University Press Archive.

Figure 1. An original example from a six voice-part manuscript by John Taverner, copied from the Tudor Church Music Prospectus, 1922. By kind permission of the Oxford University Press Archive. 